\title{
Effects of a novel heat-treated protein and carbohydrate supplement on feed consumption, milk production, and cheese yield in early-lactation dairy cows
}

\author{
M. R. Sheehy, ${ }^{1,2}$ F. J. Mulligan, ${ }^{1 *}$ (1) S. T. Taylor, ${ }^{2}$ and A. G. Fahey ${ }^{3}$ \\ ${ }^{1}$ School of Veterinary Medicine, University College Dublin, D04 V1W8, Ireland \\ ${ }^{2}$ Devenish Nutrition Ltd., Belfast, BT1 3 BG, Northern Ireland \\ ${ }^{3}$ School of Agriculture and Food Science, University College Dublin, D04 V1W8, Ireland
}

\section{ABSTRACT}

Protein is an expensive component of the dairy cow diet, and overfeeding protein can have adverse economic and environmental impacts. Our objective was to maintain milk production and components while decreasing dietary crude protein (CP) through use of a heat-treated, rumen-resistant sugar amino acid complex (SAAC) as the Schiff base, as an addition to low-protein diets. Dietary treatments included a negative control [NC, $146 \mathrm{~g}$ of $\mathrm{CP} / \mathrm{kg}$ of dry matter (DM)], a positive control $(\mathrm{PC}, 163 \mathrm{~g}$ of $\mathrm{CP} / \mathrm{kg}$ of $\mathrm{DM})$, and the NC supplemented with SAAC in lieu of some barley grain (SAAD, $151 \mathrm{~g}$ of $\mathrm{CP} / \mathrm{kg}$ of $\mathrm{DM})$. Diets were fed to 30 multiparous Holstein-Friesian dairy cows for the first $50 \mathrm{~d}$ postpartum. Dry matter intake (DMI) was determined daily. Milk yield and content of fat, protein, lactose, and casein were recorded weekly from wk 2 to 7 of lactation. The fixed effects of treatment, week, treatment $\times$ week, month of calving, and BCS at calving, and a random effect of cow, were analyzed using the MIXED procedure of SAS (SAS Institute Inc., Cary, NC). The SAAD treatment had greater energycorrected milk yield than did NC. The PC treatment had greater DMI than did NC, and SAAD tended to have greater DMI than did NC. We found significant treatment effects for fat percentage and yield. The NC and SAAD treatments had higher fat percentages than did PC, and SAAD had a higher fat yield than did the $\mathrm{NC}$ and PC treatments. Treatment effects were found for casein yield and percentage. We discovered a treatment effect for protein percentage and yield. The PC treatment had higher protein percentage than did NC and SAAD. The PC treatment had a higher protein yield than did NC, and analysis revealed no difference in protein yield between $\mathrm{PC}$ and SAAD. The SAAD treatment had higher total milk solids than did the NC

Received August 19, 2019.

Accepted December 20, 2019.

*Corresponding author: finbar.mulligan@ucd.ie treatment. Lactose yield tended to be higher in PC than in $\mathrm{NC}$, and no differences were found between $\mathrm{PC}$ and $\mathrm{NC}$ and SAAD treatments. The PC treatment had a higher casein percentage than did NC and SAAD; however, the SAAD and PC treatments had higher casein yields than did NC. The PC treatment had a higher casein:fat ratio than did the $\mathrm{NC}$ and SAAD treatments. The NC and SAAD treatments had higher Cheddar cheese yields than did PC. We found no treatment $x$ week interactions for any parameter. Supplementing low-protein dairy cow diets with a heat-treated, rumenresistant SAAC caused beneficial effects by improving milk components and increasing cheese yield to levels similar to those found when feeding expensive and environmentally damaging high-protein diets.

Key words: milk production, protein, carbohydrate, Schiff base

\section{INTRODUCTION}

Dairy cows require a supply of metabolizable protein for maintenance, growth, reproduction, and milk protein synthesis (Schwab and Broderick, 2017; Moraes et al., 2018). This metabolizable protein is largely derived from microbial protein that is generated from rumenavailable protein supplied in the diet. However, higherproducing cows also require protein supplementation that bypasses the rumen (RUP) and releases AA for absorption in the lower intestinal tract (Patton et al., 2014; Lee et al., 2015). Protein supplementation represents a large proportion of the cost of feeding dairy cows (Pacheco et al., 2012; Sinclair et al., 2014). Overfeeding of $\mathrm{CP}$ to obtain maximal milk yield and composition is a common practice (St-Pierre and Thraen, 1999) to ensure an adequate supply of all AA to support biological functions (Patton et al., 2014) and mask possible ingredient deficiencies (Pacheco et al., 2012). Increasing dietary $\mathrm{CP}$ has adverse environmental impacts through increased nitrogen excretion (Kidane et al., 2018) and possible adverse production effects because of a linear increase in blood urea, which reportedly reduces fertil- 
ity (Lean et al., 2012), decreases the efficiency of $\mathrm{N}$ utilization (Broderick, 2003), and increases the polluting potential of dairy cow excreta (Pakrou and Dillon, 1995).

The aim of efficient dairy cow nutrition should be to maximize productive response with minimal dietary protein, and this can be achieved by tailoring the balance of absorbable AA to the requirements of the cow (Cabrita et al., 2011). Twenty AA are required to build proteins, and, of these, 9 are considered essential AA, as the cow cannot produce them herself (NRC, 2001). Balancing diets for AA is a mitigation strategy for adverse environmental effects and may offer the opportunity to improve the economics of dairy production (Patton et al., 2014). Meeting the AA requirements of the cow with minimal dietary protein requires maximizing rumen synthesis of microbial protein in the rumen, and altering the AA composition of dietary protein (Schwab and Ordway, 2004) can be achieved through selective use of protein supplements and use of rumen-protected AA (Schwab, 2012).

One consequence of the method used to supply rumenbypass amino acids in this case will be the supply of sugar (sucrose) for digestion post-ruminally. Although additional dietary sucrose has been found to increase $3.5 \%$ FCM especially for cows producing more than 33 $\mathrm{kg}$ of milk per day (de Ondarza et al., 2017), very little data are available on the effects of rumen-bypass sugar on milk production or composition in dairy cows. However, it could reasonably be expected that this supply of digestible carbohydrate postruminally may improve the glucogenic nutrient supply to the mammary.

The objective of this study was to reduce the $\mathrm{CP}$ content of dairy cow diets to reduce nitrogen excretion. However, we wanted to evaluate whether a discrete sugar

Table 1. Proportional protein disappearance for SAAC, unheated ingredients in SAAC, and heat-treated soybean meal after 0-, 4-, 8-, and 12 -h incubation in sacco

\begin{tabular}{lcccc}
\hline Item & $0 \mathrm{~h}$ & $4 \mathrm{~h}$ & $8 \mathrm{~h}$ & $12 \mathrm{~h}$ \\
\hline SAAC $^{1}$ & 0.443 & 0.491 & 0.580 & 0.655 \\
Unheated SAAC ingredients $_{\text {Heat-treated soybean meal }}^{2}$ & 0.685 & 0.715 & 0.758 & 0.814 \\
\hline
\end{tabular}

${ }^{1}$ SAAC $=$ sugar amino acid complex. SAAC contained only maize, soybean meal, molasses, and synthetic amino acids, and had the following chemical composition: CP $223 \mathrm{~g} / \mathrm{kg}$ of DM, starch $325 \mathrm{~g} / \mathrm{kg}$ of DM, sugar $74 \mathrm{~g} / \mathrm{kg}$ of DM, lysine $30 \mathrm{~g} / \mathrm{kg}$ of DM, and methionine $17.5 \mathrm{~g} / \mathrm{kg}$ of DM. The $20 \mathrm{~g} / \mathrm{kg}$ of DM of lysine and $15 \mathrm{~g} / \mathrm{kg}$ of DM of methionine were in the form of commercially available synthetic amino acids, as lysine $\mathrm{HCl}$ and DL-methionine, respectively. This mixture of ingredients was heat-treated to create a Schiff base product.

${ }^{2}$ Heat-treated soybean meal (Bypro, Devenish Nutrition Ltd., Belfast, Northern Ireland) contained only $99 \%$ heat-treated soybean meal and synthetic methionine. and amino acid supplement could maintain performance levels similar to those achieved with high-protein diets when offered in addition to the low-protein diet. The supplement used was a a heat-treated, rumen-resistant sugar amino acid complex created through the Schiff base reaction, an intermediate in the Maillard reaction process (Gordon et al., 1993).

\section{MATERIALS AND METHODS}

This study was approved by the Animal Research Ethics Committee of University College Dublin (UCD; Ireland) and was licensed by the Irish Medicine Board, pursuant to part 8 of the European Union (Protection of Animals Used for Scientific Purposes) regulations SI 543 of 2012.

\section{Experimental Dairy Cows}

Thirty multiparous Holstein Friesian dairy cows from the herd at UCD Lyons Research Farm, Celbridge, Kildare, IE $\left(53^{\circ} 17^{\prime} 56^{\prime \prime} \mathrm{N}, 6^{\circ} 32^{\prime} 18^{\prime \prime} \mathrm{W}\right)$ were stratified based on parity and calving date and assigned to 1 of 3 isoenergetic TMR diets. Dietary treatments included a negative control (NC, $146 \mathrm{~g}$ of $\mathrm{CP} / \mathrm{kg}$ of $\mathrm{DM})$, positive control (PC, $163 \mathrm{~g}$ of $\mathrm{CP} / \mathrm{kg}$ of $\mathrm{DM}$ ), and a sugar amino acid complex-supplemented NC $\operatorname{diet}$ (SAAD, $151 \mathrm{~g}$ of $\mathrm{CP} / \mathrm{kg}$ of $\mathrm{DM})$, with 10 cows per treatment in a randomized complete block design. The sugar amino acid complex (SAAC) was designed to be a rumen-resistant product, and its proportional protein disappearance is outlined in Table 1 . The SAAD was created by replacing some of the barley grain in the $\mathrm{NC}$ diet with the heat-treated, rumen-resistant product (Table 2). The rumen-resistant product was created through a Schiff base reaction, an intermediate in the Maillard reaction process, which renders the AA resistant to rumen fermentation but available for digestion and subsequent absorption in the lower digestive tract (Gordon et al., 1993). Treatment groups were balanced for previous 305 -d lactation milk yield $(7,861 \pm 919 \mathrm{~kg})$, milk protein yield $(270 \pm 34.3 \mathrm{~kg})$, milk fat yield $(341 \pm 44.6$ $\mathrm{kg})$, BCS $(3.1 \pm 0.25)$, and BW $(626 \pm 71 \mathrm{~kg})$ postpartum $(\mathbf{P P})$. Following parturition (d 0), there was a 7-d covariate period, with cows receiving conventional grass and maize silage plus in-parlor concentrate feeding. Subsequently, supplementation of the experimental diets commenced on d $8 \mathrm{PP}$ and concluded on d $49 \mathrm{PP}$. All cows had ad libitum access to water and were offered their respective dietary treatments as a TMR on a daily basis. The TMR was achieved using an experimental diet feeder (American Callan, Northwood, NH). The ingredient inclusion rate of each dietary treatment 
is presented in Table 2. Individual fresh feed intake was recorded using electronic feed boxes (RIC System, Insentec B.V., Marknesse, the Netherlands).
For the duration of the experiment, cows were housed indoors in freestall accommodation and were milked twice daily at $0700 \mathrm{~h}$ and $1600 \mathrm{~h}$. Milk output was

Table 2. Ingredients, chemical compositions, and predicted nutrient profiles of dietary treatments

\begin{tabular}{|c|c|c|c|}
\hline Item & Negative control & Positive control & $\mathrm{SAAD}^{3}$ \\
\hline \multicolumn{4}{|c|}{ Ingredient composition ( $\mathrm{g} / \mathrm{kg}$ of $\mathrm{DM})$} \\
\hline Grass silage & 288 & 288 & 286 \\
\hline Maize silage & 316 & 316 & 314 \\
\hline Barley & 61 & 20 & 20 \\
\hline Unmolassed sugar beet pulp & 42 & 42 & 41 \\
\hline Soybean meal $(48 \%)$ & 20 & 61 & 20 \\
\hline Dairy Nut ${ }^{1}$ & 269 & 269 & 268 \\
\hline Lithothamnian $^{2}$ & 4 & 4 & 4 \\
\hline $\mathrm{SAAC}^{3}$ & 0 & 0 & 47 \\
\hline \multicolumn{4}{|l|}{$\begin{array}{l}\text { Chemical composition } \\
\text { (g/kg of DM unless otherwise } \\
\text { indicated) }\end{array}$} \\
\hline $\mathrm{DM}(\mathrm{g} / \mathrm{kg})$ & 453 & 458 & 453 \\
\hline $\mathrm{ADF}$ & 247 & 234 & 235 \\
\hline NDF & 386 & 370 & 369 \\
\hline Ether extract & 28 & 26 & 29 \\
\hline $\mathrm{CP}$ & 146 & 163 & 151 \\
\hline Crude fiber & 207 & 196 & 197 \\
\hline Starch & 136 & 170 & 165 \\
\hline Sugar & 56 & 57 & 59 \\
\hline ADL & 23 & 26 & 28 \\
\hline $\mathrm{NE}_{\mathrm{L}}(\mathrm{Mcal} / \mathrm{kg}$ of DM) & 1.61 & 1.62 & 1.62 \\
\hline $\operatorname{PDIN}^{4}(\mathrm{~g} / \mathrm{d})$ & 2,036 & 2,314 & 2,158 \\
\hline $\operatorname{PDIE}^{5}(\mathrm{~g} / \mathrm{d})$ & 2,049 & 2,192 & 2,155 \\
\hline PDIN (g/kg of DM) & 96.49 & 109.67 & 102.27 \\
\hline PDIE $(\mathrm{g} / \mathrm{kg}$ of $\mathrm{DM})$ & 97.11 & 103.89 & 102.13 \\
\hline $\operatorname{LysDI}^{6}(\%$ of PDIE) & 6.47 & 6.51 & 7.07 \\
\hline $\operatorname{MetDI}^{7}(\%$ of PDIE) & 1.78 & 1.75 & 2.32 \\
\hline LysDI:MetDI & 3.63 & 3.72 & 3.05 \\
\hline \multicolumn{4}{|l|}{ Mineral $(\mathrm{g} / \mathrm{kg}$ of $\mathrm{DM})$} \\
\hline Calcium & 7.13 & 7.23 & 7.21 \\
\hline Phosphorus & 3.68 & 3.83 & 3.85 \\
\hline Magnesium & 2.88 & 2.85 & 2.84 \\
\hline Potassium & 12.36 & 13.16 & 13.22 \\
\hline Sodium & 1.99 & 1.99 & 1.98 \\
\hline Chloride & 2.75 & 2.75 & 2.75 \\
\hline Sulfur & 2.07 & 2.20 & 2.21 \\
\hline \multicolumn{4}{|l|}{ Trace element (mg/kg of DM) } \\
\hline Manganese & 54.68 & 55.72 & 55.72 \\
\hline Copper & 15.45 & 15.81 & 15.80 \\
\hline Zinc & 45.41 & 46.33 & 46.32 \\
\hline Cobalt & 2.66 & 2.73 & 2.72 \\
\hline Iodine & 2.73 & 2.73 & 2.73 \\
\hline Selenium & 0.33 & 0.34 & 0.34 \\
\hline Iron & 128.04 & 131.03 & 127.95 \\
\hline
\end{tabular}

${ }^{1}$ Gain Feeds, Glanbia PLC, Kilkenny, Ireland. Ingredient composition in descending order: wheat, rapeseed meal, gluten feed, soybean meal, maize distillers, maize, palm kernel, whey, citrus pulp, sugar beet pulp, oats, soy hulls, vegetable oil, and minerals. Chemical composition: CP $218 \mathrm{~g} / \mathrm{kg}$ of DM, starch $229 \mathrm{~g} / \mathrm{kg}$ of DM, and sugar $54 \mathrm{~g} / \mathrm{kg}$ of DM.

${ }^{2}$ Calcereous marine algae (AcidBuf), Celtic Sea Minerals, Cork, Ireland.

${ }^{3}$ SAAC $=$ sugar amino acid complex; SAAD = sugar amino acid complex diet. The SAAC contained only maize, soybean meal, molasses, and synthetic amino acids, and had the following chemical composition: $\mathrm{CP}$ $223 \mathrm{~g} / \mathrm{kg}$ of DM, starch $325 \mathrm{~g} / \mathrm{kg}$ of DM, sugar $74 \mathrm{~g} / \mathrm{kg}$ of DM, lysine $30 \mathrm{~g} / \mathrm{kg}$ of DM, and methionine $17.5 \mathrm{~g} /$ $\mathrm{kg}$ of DM. Twenty $\mathrm{g} / \mathrm{kg}$ of DM of lysine and $15 \mathrm{~g} / \mathrm{kg}$ of DM of methionine were in the form of commercially available synthetic amino acids as lysine $\mathrm{HCl}$ and DL-methionine, respectively. This mixture of ingredients was heat-treated to create a Schiff base product.

${ }^{4} \mathrm{PDIN}=$ protein truly digested in the small intestine, where nitrogen limits microbial protein synthesis.

${ }^{5} \mathrm{PDIE}=$ protein truly digested in the small intestine, where energy limits microbial protein synthesis.

${ }^{6} \mathrm{LysDI}=$ lysine truly digested in the small intestine.

${ }^{7} \mathrm{MetDI}=$ methionine truly digested in the small intestine. 
automatically recorded at a.m. and p.m. milkings using the Weighall milk meter system (Dairymaster, Kerry, Ireland).

\section{Diets}

Diets were formulated to meet the nutritional requirements for the production of $33 \mathrm{~L}$ of milk with $4.0 \%$ fat and $3.2 \%$ protein for a $600-\mathrm{kg}$ cow (Jarrige, 1989; Inration 4.07, Educagri, Dijon, France) and are detailed in Table 2. Diets were based on grass silage, maize silage, unmolassed sugar beet pulp, and a proprietary dairy nut. The treatments were created using varying levels of soybean meal (48\%), barley, and the SAAC. The SAAC contained only maize grain, soybean meal, molasses, and synthetic amino acids, and had the following chemical composition: CP $223 \mathrm{~g} / \mathrm{kg}$ of DM, starch $325 \mathrm{~g} / \mathrm{kg}$ of DM, sugar $74 \mathrm{~g} / \mathrm{kg}$ of DM, lysine $30 \mathrm{~g} / \mathrm{kg}$ of DM, and methionine $17.5 \mathrm{~g} / \mathrm{kg}$ of DM. A total of $20 \mathrm{~g} / \mathrm{kg}$ of DM of lysine and $15 \mathrm{~g} / \mathrm{kg}$ of DM of methionine were used, in the form of commercially available synthetic amino acids, as lysine $\mathrm{HCl}$ and $\mathrm{DL}-$ methionine, respectively. This mixture of ingredients was heat-treated to create a Schiff base product.

Diets were formulated to be isoenergetic (1.62 Mcal of $\mathrm{NE}_{\mathrm{L}} / \mathrm{kg}$ of $\mathrm{DM}$ ). Lysine and methionine supply was consistent as a percentage of the true protein absorbable in the small intestine when energy is the limiting factor (PDIE) in both the $\mathrm{NC}$ and $\mathrm{PC}$ diets but was increased by 10 and $20 \%$, respectively, in the SAAD treatment (Table 2).

\section{Feed Analysis}

Total mixed ration and component ingredient samples were collected weekly and stored at $-20^{\circ} \mathrm{C}$ for analysis. Maize and grass silage DM was determined by drying in an oven for $72 \mathrm{~h}$ at $55^{\circ} \mathrm{C}$. All concentrate ingredients and forage samples were milled through a $1-\mathrm{mm}$ screen using a Christy and Norris hammer mill (Christy and Norris Process Engineers Ltd., Chelmsford, UK), dried at $105^{\circ} \mathrm{C}$ for a minimum of $16 \mathrm{~h}$ to determine the residual DM, and placed in a muffle furnace at $550^{\circ} \mathrm{C}$ for $4 \mathrm{~h}$ (Nabertherm, Bremen, Germany) to determine the ash component. Crude protein was calculated as $\mathrm{N} \times 6.25$ using the Leco FP 528 instrument (Leco Instruments UK Ltd., Stockport, UK). The NDF and ADF contents of feed were measured according to the procedures of Van Soest et al. (1991) using a Fibertec extraction unit (Tecator, Höganäs, Sweden) and heat-stable $\alpha$-amylase (FAA, Ankom Technology, Macedon, NY) to degrade the starch in the concentrate and maize silage samples.
Starch in the maize silage was determined using the Megazyme total starch assay kit (Megazyme International Ireland Ltd., Bray, Ireland) according to AOAC International (2001).

\section{Milk Collection and Analysis}

Milk and component yields were recorded for individual cows every week. Milk samples were collected at consecutive a.m. and p.m. milkings once per week; and the samples were pooled in proportion to their a.m. and p.m. yields. These composite milk samples were preserved (Broad Spectrum Microtabs, D\&F Control Systems Inc., Dublin, CA) and refrigerated until they were analyzed for fat, protein, and lactose concentrations via mid-infrared reflectance spectroscopy (MilkoScan, Foss Analytics, Hillerød, Denmark). Total milk yield, fat, protein, and lactose percentages and yields, as well as SCC, were also recorded. Energy-corrected milk was calculated as $(0.3246 \times$ kilograms of milk $)+(12.86 \times$ kilograms of fat) $+(7.04 \mathrm{~kg}$ of protein) (Tyrrell and Reid, 1965). Cheddar cheese yield was calculated as $[(0.93 \times$ fat percentage $)+($ casein percentage -0.01$)$ $\times$ 1.09]/1 - moisture content (Van Slyke and Price, 1936), where cheese moisture content was assumed to be $35 \%$.

\section{In Sacco Evaluation of Heat-Treated SAAC}

In sacco protein degradability determinations were carried out for the SAAC, the mixture of ingredients used in SAAC without heat treatment, and a commercially available source of heat-treated rumen-bypass soybean meal (Bypro, Devenish Nutrition Ltd., Belfast, UK; containing only $99 \%$ heat-treated soybean meal and synthetic methionine) for comparative purposes. In sacco determinations were made using 6 rumenfistulated dairy cows. In sacco filter bags $(5 \times 10 \mathrm{~cm}$; $50-\mu \mathrm{m}$ pore size; Ankom Technology) containing approximately $5 \mathrm{~g}$ of feed material were placed inside large mesh nylon fishnet bags and inserted into the rumen of each animal for 4,8 , and $12 \mathrm{~h}$ (2 bags per time point). The feed materials used were previously ground using a Norris hammer mill fitted with a 2-mm screen (Lab Mill, Christy Turner, Suffolk, UK). After removal from the rumen, all bags were immediately submerged in ice-cold water, thoroughly washed, and stored at $-20^{\circ} \mathrm{C}$. On thawing, all bags were stomached using a Lab Blender (Seward Medical, London, UK) to remove any microbial debris, washed for $35 \mathrm{~min}$ in a washing machine and dried at $55^{\circ} \mathrm{C}$ for $72 \mathrm{~h}$ so that the $\mathrm{DM}$ residue could be determined. In sacco bags representing 
$0 \mathrm{~h}$ incubation were also subjected to these procedures. Residues were analyzed for nitrogen using a Leco FP 528 instrument (Leco Instruments UK Ltd.).

\section{Statistical Analysis}

Diagnostic tests were conducted using the UNIVARIATE procedure of SAS (v. 9.4; SAS Institute Inc., Cary, $\mathrm{NC)}$ to determine whether the residuals of the data had normal distributions. Data with residuals that were not normally distributed were transformed using a Box-Cox transformation, as previously described by Fahey et al. (2007). Somatic cell count was transformed to SCS using the formula SCS $=\log _{2}(\mathrm{SCC} / 100,000)$ + 3 (Schutz, 1994). Data were analyzed as a randomized complete block design with repeated measures. Cow was considered to be the experimental unit. The model included fixed effects for treatment (NC, PC, or SAAD), week relative to parturition (wk 2 to 7 ), lactation (2 or greater), calving month (January or February), and their interactions. The repeated measures analysis was based on week, with the most appropriate covariance structure for each parameter selected using the Bayesian information criteria (BIC). Compound symmetry was the covariance structure that had the lowest BIC for all variables. Cow was included as a random effect. Results that had a $P$-value $\leq 0.10$ were considered a statistical tendency, and $P$-value $\leq 0.05$ were considered statistically significant. A Bonferroni multiple comparison adjustment was used.

\section{RESULTS}

The proportional protein disappearance of the SAAC is shown in Table 1 . Table 3 shows that there was an overall effect of week for milk yield $(P<0.01)$ and ECM $(P<0.10)$. Although we found no overall effect of treatment for ECM, a pairwise comparison of treatments revealed that SAAD had a higher ECM than did NC $(P<0.05)$.

An overall effect of treatment $(P<0.05)$ and week $(P$ $<0.01$ ) was found for DMI. We found that NC had a lower DMI than did PC $(P<0.05)$, and NC tended to have a lower DMI than did SAAD $(P<0.10)$. Within week, NC had lower DMI than did PC at wk $4(P<$ $0.05)$ and tended to have a lower DMI at wk $5(P<$ 0.10). The ECM:DMI ratio was estimated, to determine how much DMI for each treatment was converted to ECM. Analysis revealed no overall treatment effect but a significant week effect $(P<0.01)$. The $\mathrm{NC}$ treatment had a higher ECM:DMI than did PC $(P<0.05)$ and tended to have a higher ECM:DMI than did the SAAD treatment $(P<0.10)$. We found no differences between the PC and SAAD treatments.

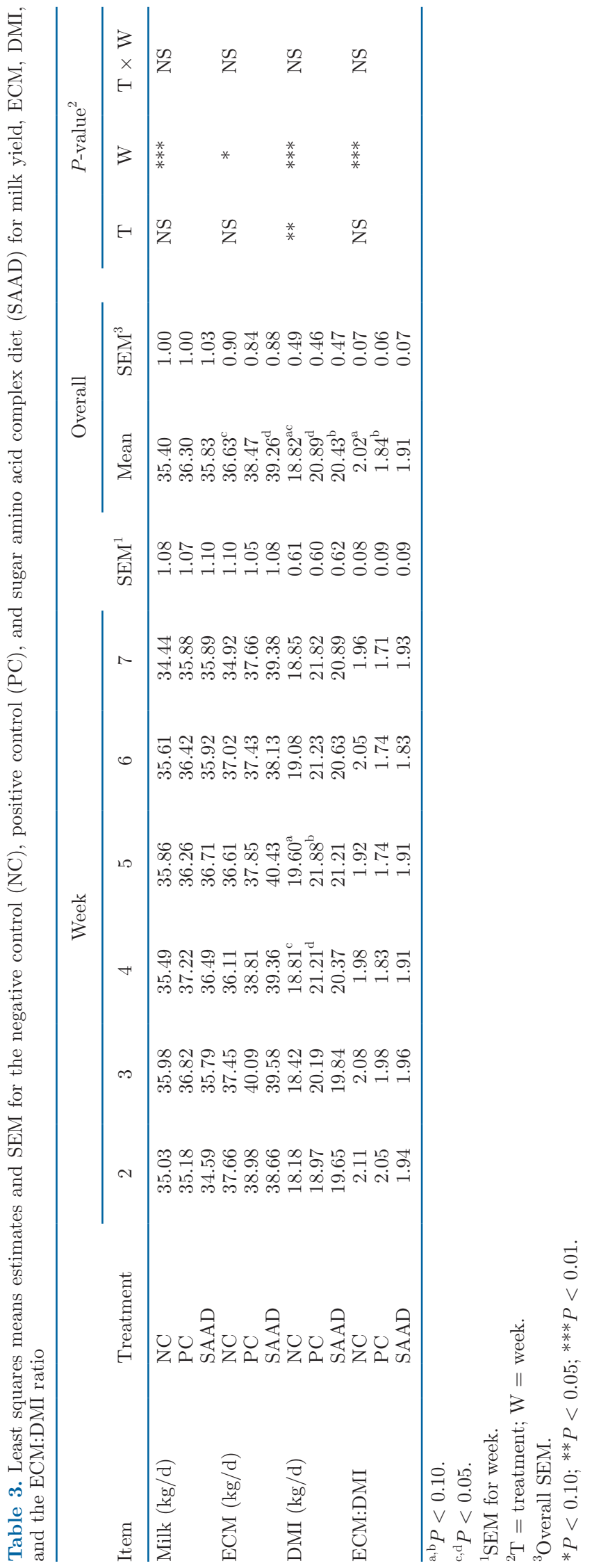


Table 4. Least squares means estimates and SEM for the negative control (NC), positive control (PC), and sugar amino acid complex diet (SAAD) for fat, protein, and lactose yields and percentages

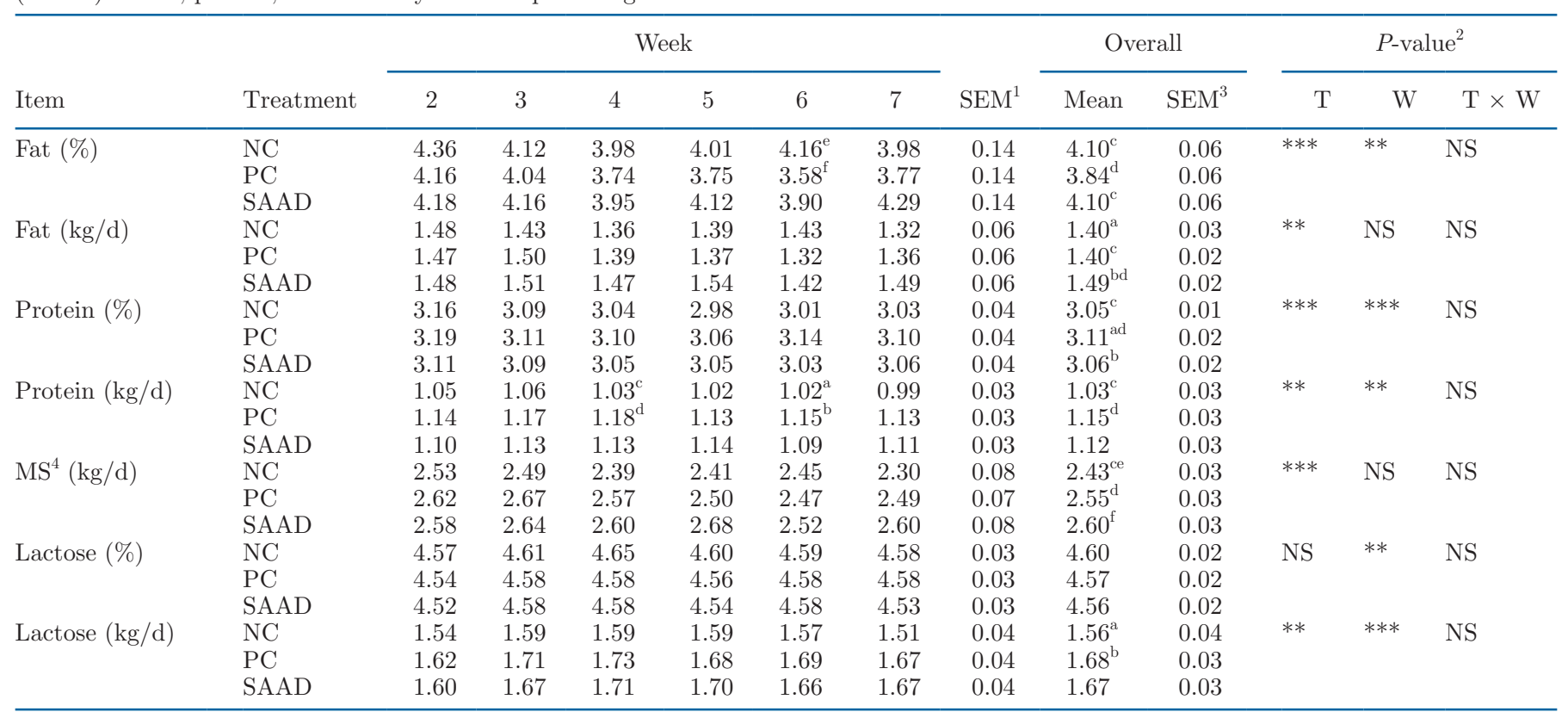

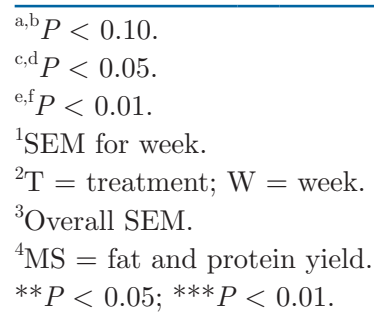

The results for milk composition are shown in Table 4. Overall treatment $(P<0.01)$ and week effects $(P$ $<0.05)$ were found for fat percentage. The $\mathrm{NC}$ and SAAD treatments had higher fat percentages than did the PC treatment $(P<0.05)$. Within week, NC had a higher fat percentage than did $\mathrm{PC}$ at wk $6(P<0.01)$. We found an overall treatment effect for fat yield $(P<$ 0.05). Treatment pairwise comparisons showed that the SAAD treatment tended to have higher fat yields than did the NC treatment $(P<0.10)$ and higher fat yields than did the PC treatment $(P<0.05)$.

Our analysis revealed significant treatment $(P<$ $0.01)$ and week $(P<0.01)$ effects for protein percentage (Table 4). Pairwise treatment comparisons showed that the $\mathrm{PC}$ treatment tended to have a higher protein percentage than did the SAAD treatment $(P<0.10)$ and a higher protein percentage than the NC treatment $(P<0.05)$. Significant treatment $(P<0.05)$ and week $(P<0.05)$ effects were found for protein yield. The PC treatment had higher protein yields than did the NC treatment $(P<0.05)$; however, we found no differences between the SAAD and the $\mathrm{PC}$ or the $\mathrm{NC}$ treatments. Within week, the PC treatment had higher protein yields at wk $4(P<0.05)$ and wk $6(P<0.05)$ compared with NC. A treatment effect was found for milk solid yield $(P<0.05)$. The NC treatment had lower milk solids than PC $(P<0.05)$ and SAAD $(P<$ $0.01)$; however, no differences appeared between the PC and SAAD treatments (Table 4).

No treatment effects were found for lactose percentage; however, there was a treatment effect $(P<0.05)$ and a week effect $(P<0.01)$ for lactose yield. Withintreatment pairwise comparison showed that PC tended to have higher lactose yields than NC. However, we found no differences between the SAAD and the NC and PC treatments.

Significant treatment $(P<0.01)$ and week $(P<$ 0.05 ) effects were found for casein percentage (Table $5)$. The PC treatment had a higher casein percentage than did the NC and SAAD treatments $(P<0.05)$. An overall treatment effect was found for casein yield $(P<0.01)$. The PC and SAAD treatments had higher casein yields than did the NC treatment $(P<0.01)$; however, we found no difference between the PC and SAAD treatments. A treatment effect was found for the casein:fat ratio $(P<0.01)$. The $\mathrm{PC}$ treatment had 
a greater casein:fat ratio than both the NC and SAAD treatments $(P<0.01)$. However, no difference appeared between the NC and SAAD treatments (Table 5). Within week, the PC treatment had a higher casein: fat ratio than $\mathrm{NC}$ at wk $6(P<0.01)$, and the $\mathrm{PC}$ treatment had a higher ratio of casein:fat than SAAD at wk $7(P<0.01)$. Analysis revealed an overall treatment $(P$ $<0.05)$ and week $(P<0.01)$ effect for Cheddar cheese yield (CCY; Table 5). The SAAD and NC treatments had a higher $\mathrm{CCY}$ than the PC treatment $(P<0.05)$ and we discovered no difference between the SAAD and $\mathrm{NC}$ treatments. Within week, the NC treatment tended to have a higher $\mathrm{CCY}$ than did the PC treatment at wk $6(P<0.10)$.

\section{DISCUSSION}

The objective of this study was to determine whether a SAAC synthesized as the Schiff base can be used in a lower-CP diet to maintain milk and component yields in early lactation. Methionine and lysine are considered the first 2 limiting AA for milk production when diets are based on corn ingredients (NRC, 2001; Südekum et al., 2004). According to NRC (2001), methionine is considered to be limiting when diets are low in corn or rich in forage or when the supplemented RUP is provided by soybean products. Overfeeding of CP has been a management strategy often used to ensure that the cow gets an adequate amount of AA in her diet (St-Pierre and Thraen, 1999). However, protein supplementation represents a large proportion of the cost of feeding dairy cows (Pacheco et al., 2012). Furthermore, feeding excess protein has adverse environmental effects, such as increased urinary urea concentrations (Patton et al., 2014). Previous work in our laboratory has demonstrated the successful use of amino acids in lower-protein diets through increased milk production (Whelan et al., 2012). Swine and poultry diets are currently formulated on an AA basis, and a more targeted protein nutrition approach in the dairy industry may be warranted. The first step toward formulating dairy cow diets on an AA basis may be the use of nutritional bypass technologies to increase the amount of AA that are protected from the rumen and reach the small intestine.

A review of the literature shows that supplementing the diet with RUP has varied effects on milk production (Zanton et al., 2014). A meta-analysis of 64 studies that looked at the effects of supplementing dairy diets with methionine or postruminal infusion of methionine from different sources found no effect on milk yield; these methionine supplementations were added to diets ranging from 11 to $22.5 \% \mathrm{CP}$. However, there was a tendency to increase milk yield when supplemented with 2-hydroxy-4-methylthio butanoic acid (HMTBa) and Mepron (Evonik Industries, Essen, Germany; Zanton et al., 2014). Zhou et al. (2016) found positive milk yield responses to rumen-protected methionine (RPM) in early lactation (up to 30 DIM). However, Batistel et al. (2017) achieved a $4.1 \mathrm{~kg} / \mathrm{d}$ milk yield response (until 30 DIM) and a $4.4 \mathrm{~kg} / \mathrm{d}$ milk yield response through peak lactation (30 to 60 DIM) from feeding ethyl-cellulose RPM. It was suggested by Zhou et al. (2016) that this increase in milk yield was likely to be the result of increased DMI. In our study we did not find differences for milk yield between the 3 treatments; however, the SAAD treatment had significantly greater ECM than did the NC treatment.

Additionally we found that the PC and SAAD treatments had significant increases in DMI compared with the NC treatment. The increase in DMI is in agreement with previous studies, which found that when cows were supplemented with methionine PP, their DMI increased (Ordway et al., 2009; Osorio et al., 2013). However, Chen et al. (2011) found that supplementation with methionine over a 12 -wk period did not have an effect on DMI for cows that were more than 88 DIM. Similarly, in the prepartal period, methionine supplementation had no effect on DMI (Socha et al., 2005; Ordway et al., 2009). These inconsistent results could be related to differences in the level of methionine supplementation, duration of feeding, stage of lactation, or different control diets. In relation to these differences, Socha et al. (2005) found that the greatest response to optimal lysine and methionine nutrition occurred during early lactation for ECM, milk true protein, and fat content, when the requirement for absorbed AA relative to absorbed energy is greatest. However, Batistel et al. (2017) found that ethyl-cellulose RPM supplementation increased DMI in the prepartum, in the immediate $\mathrm{PP}$, and up to 60 DIM in high-producing cows (up to $50 \mathrm{~kg} / \mathrm{d}$ ). Likewise Osorio et al. (2013) and Zhou et al. (2016) found increased DMI and better liver function in the early PP period with RPM supplementation. Schwab et al. (1992) demonstrated that the correct balance of absorbable AA has a beneficial effect on DMI, and in another study DL-methionine and HMBi in the dairy cow diet improve fiber digestion (Noftsger et al., 2005).

In our study, efficiency was estimated as the ratio between ECM and DMI. The efficiency of SAAD was intermediate and not different between $\mathrm{NC}$ and $\mathrm{PC}$. However, the $\mathrm{NC}$ was more efficient that the PC treatment. Even though SAAD had a greater amount of 


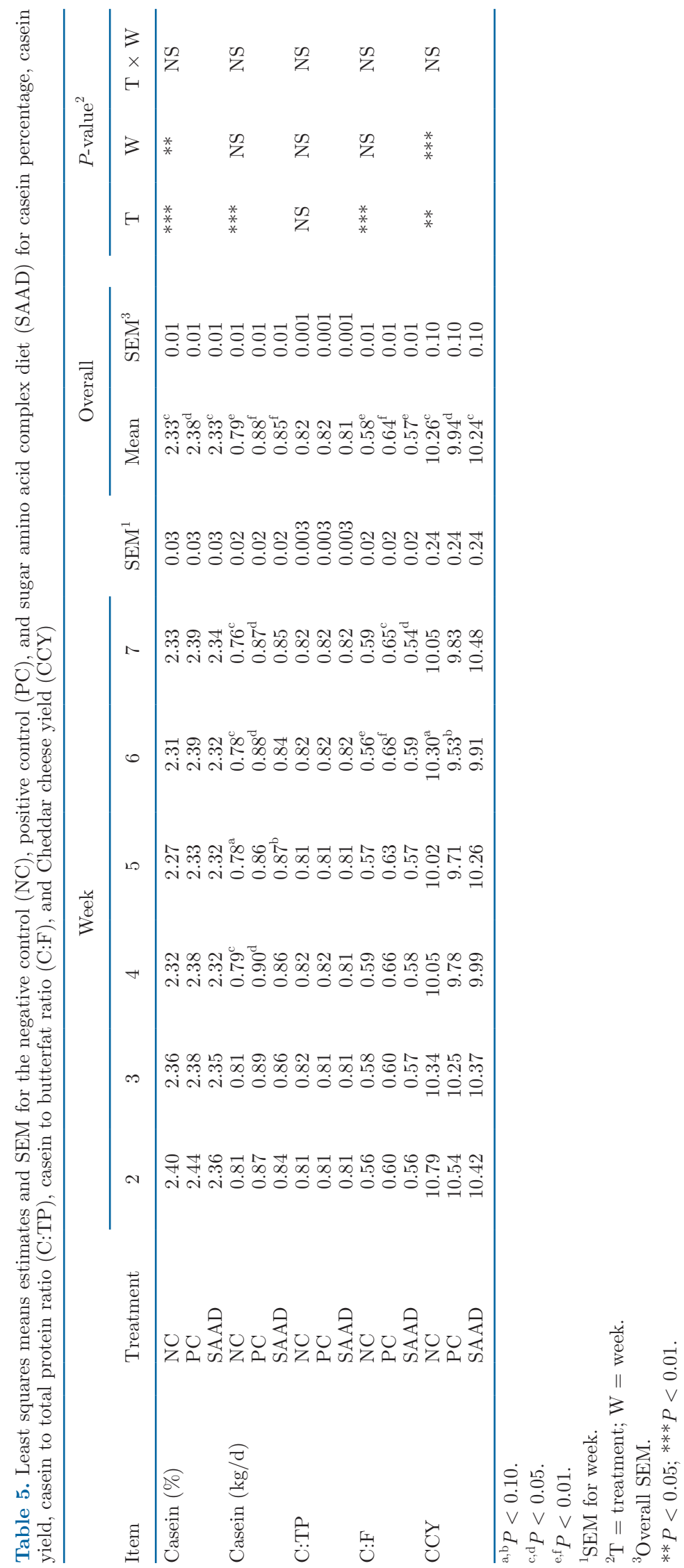


protected AA and some rumen-resistant carbohydrate, we did not see an increase in ECM:DMI. However, previous studies did find improvement to ECM:DMI when basal diets were supplemented with RPM or RPM and lysine (Socha et al., 2005; Chen et al., 2011; Osorio et al., 2013). The ECM:DMI did not improve for cows on the SAAD treatment, as it was associated with in an increase in DMI. The increase in DMI was not seen in a previous study, which found no effect on DMI when feeding RPM compared with a control diet (Osorio et al., 2013). Although efficient ECM:DMI is important in the overall lactation, it can be a distinct disadvantage in early lactation, because higher ECM:DMI may be associated with increased BCS losses and greater deficiencies in energy balance.

The SAAD treatment demonstrated improvements in milk fat percentage compared with $\mathrm{PC}$ and improved milk fat yield compared with the $\mathrm{PC}$ and $\mathrm{NC}$ treatments. These results are similar to those of previous studies that were used in a meta-analysis of diets supplemented with RPM (Patton, 2010), which used 2 studies that showed an association between RPM and increases in fat percentage (Overton et al., 1998; Samuelson et al., 2001). Similarly, the meta-analysis study conducted by Patton (2010) referenced 3 studies where increases in RPM supplementation caused increases in fat yield (Overton et al., 1996; Schmidt et al., 1999; Kröber et al., 2000). However, 2 previous studies did find that increases in RPM had lower milk fat yields (Chilliard and Doreau, 1997; Socha et al., 2005). Methionine is a methyl donor (Zanton et al., 2014) and can thereby influence milk fat and milk volume (Sharma and Erdman,1988) through its role in hepatocyte lipid transport (McCarthy et al.,1968). This is important, as Huber et al. (1984) demonstrated higher triglyceride (key substrates for milk fat synthesis) levels in blood following HMTBa supplementation.

Our study showed that providing cows with SAAC did not improve protein percentage or yield. The positive control did have a higher protein percentage than did the NC and SAAD treatments. However, the PC treatment had higher protein yields than $\mathrm{NC}$, and no difference appeared between the SAAD and PC treatments. Broderick (2003) found an increase in protein percentage when dietary $\mathrm{CP}$ was increased from 15.1 to $16.7 \%$ but did not find a further increase in protein percentage when the $\mathrm{CP}$ of the diet was increased to $18.4 \%$; moreover, in examining true protein percentage, Broderick did not find any differences across the 3 diets. This may indicate that the reported increases in protein percentages for the current study come mainly from urea, as milk CP percentage was measured. Amanlou et al. (2017) found that increasing dietary CP levels up to $19 \%$ of $\mathrm{DM}$ in the first $21 \mathrm{~d}$ of lactation increased DMI, milk yield, and yields of milk protein and lactose. This agrees with the findings of Broderick et al. (2002) and Flis and Wattiaux (2005). However, Broderick (2003) indicated that increasing CP above $16.7 \%$ in dairy cow rations had no effect on milk production or milk components. Similar results to those of our study were found when Varvikko et al. (1999) did not improve protein yield by infusions of methionine into the abomasum. Furthermore, as milk fat is the most energetically demanding component of milk (Tyrrell and Reid, 1965), it is difficult to increase both the fat and protein components of milk simultaneously. A review of the literature by Jenkins and McGuire (2006) suggested that it is easier to alter fat than protein content of milk. The beneficial effects of methionine supplementation on fiber digestion (Noftsger et al., 2005) could also explain why the fat component, rather than the protein components, was improved in the SAAD diet, as improved fiber digestion has been shown to improve milk fat content (Van Soest, 1963). Overall the SAAD treatment did have a beneficial effect on milk solids.

In the treatment comparisons considered, it is also worth remembering that rumen-available carbohydrate will be supplied by the SAAC, as will rumen-bypass carbohydrates. It could be expected that the rumenavailable carbohydrate will increase yields of VFA and microbial protein. These effects will be important for production responses obtained. The lactose yield for cows fed the SAAD is very similar to that of cows fed the $\mathrm{PC}$ diet, with an overall treatment effect noted for lactose yield (Table 4). It is possible that the post-ruminal supply of sugar from SAAD increased the supply of glucogenic nutrients to the mammary, thus preventing the trend of reduced lactose yield that was observed for the NC treatment $(P<0.10)$. The beneficial effect of the SAAD diet on ECM compared with the NC diet may also have been partially attributable to the rumenbypass carbohydrate. Nocek and Tamminga (1991) reported positive correlations between rumen-escape starch and DMI, milk yield, and protein yield. In the current study, protein yield was lower for NC compared with the PC diet $(P<0.05)$. However, for the SAAD diet, protein yield was not lower than for the PC. Once again, this effect may be partially attributable to the rumen-bypass carbohydrate supplied in the SAAC.

The data for casein percentage and yield showed a similar trend to protein percentage and yield (Table $5)$. The PC treatment had greater casein percentage than did NC and SAAD; however, SAAD and PC had higher casein yields than did NC. Several studies have found that the casein fraction of protein is the most affected by post-ruminal available lysine and methionine 
(Donkin et al., 1989; Robert et al., 1989; Le Henaff et al., 1990). It could be expected that PC and SAAD would have more post-ruminal lysine and methionine than NC because of the high CP content of the PC and the RUP nature of the SAAC; this would provide a suggested mechanism as to why PC and SAAD had higher casein yields.

Casein plays an important role in cheese production; therefore the CCY was estimated using the Van Slyke formula (Van Slyke and Price, 1936). Supplementation with SAAD was found to improve CCY compared with $\mathrm{PC}$ because of the similar casein yields between the 2 treatment and the higher fat percentage in the SAAD treatment. These findings are consistent with those of El-Gawad and Ahmed (2011), who found that casein and fat were important in increasing cheese yield. It has previously been shown that increases in DMI are associated with increases in cheese yield because of the higher intake of protein (Auldist et al., 1998). However, the SAAD treatment showed an increase in cheese yield and provided the cow with $1.2 \%$ less $\mathrm{CP}$ in the overall diet. The SAAD diet had a similar estimated cheese yield to that of the $\mathrm{NC}$; however, the $\mathrm{NC}$ treatment had lower milk yield. This would suggest an improved efficiency of cheese production from milk of cows in the SAAD treatment.

\section{CONCLUSIONS}

This study evaluated the effect of reducing dietary $\mathrm{CP}$ content and supplementation with a sugar amino acid complex on production in early-lactation cows. The SAAD treatment was effective in maintaining milk yield and increasing fat and casein yields. As a consequence of this, the estimated cheese yields from the milk produced were increased. These results indicate that the SAAD treatment may increase the added value of the milk produced while having the potential to reduce negative environmental effects by reducing the $\mathrm{CP}$ of the diet.

\section{ACKNOWLEDGMENTS}

This project was part funded by Devenish Nutrition Ltd (Belfast, UK). M. R. Sheehy is an employee of Devenish Nutrition Ltd. S. T. Taylor is formerly a consultant to Devenish Nutrition Ltd. The authors have not stated any conflicts of interest.

\section{REFERENCES}

Amanlou, H., T. A. Farahani, and N. E. Farsuni. 2017. Effects of rumen undegradable protein supplementation on productive per- formance and indicators of protein and energy metabolism in Holstein fresh cows. J. Dairy Sci. 100:3628-3640. https://doi.org/10 $.3168 /$ jds.2016-11794.

AOAC International. 2001. Official Methods of Analysis. 17th ed. AOAC International, Gaithersburg, MD.

Auldist, M. J., W. Van der Poel, P. Laboyrie, and C. G. Prosser. 1998. Influence of pasture allowance on the composition and cheeseyielding potential milk. Proc. New Zeal. Grass. Assoc. 60:199-202

Batistel, F., J. M. Arroyo, A. Bellingeri, L. Wang, B. Saremi, C. Parys, E. Trevisi, F. C. Cardoso, and J. J. Loor. 2017. Ethyl-cellulose rumen-protected methionine enhances performance during the periparturient period and early lactation in Holstein dairy cows. J. Dairy Sci. 100:7455-7467. https://doi.org/10.3168/jds.2017-12689.

Broderick, G. A. 2003. Effects of varing dietary protein and energy levels on the produciton of lactating dairy cows. J. Dairy Sci. 86:1370-1381. https://doi.org/10.3168/jds.S0022-0302(03)73721 -7 .

Broderick, G. A., D. Mertens, and R. Simons. 2002. Efficacy of carbohydrate sources for milk production by cows fed diets based on alfalfa silage. J. Dairy Sci. 85:1767-1776. https://doi.org/10.3168/ jds.S0022-0302(02)74251-3.

Cabrita, A. R. J., R. J. Dewhurst, D. S. P. Melo, J. M. Moorby, and A. J. M. Fonseca. 2011. Effects of dietary protein concentration and balance of absorbable amin acids on productive responses of dairy cows fed corn silage based diets. J. Dairy Sci. 94:4647-4656. https: //doi.org/10.3168/jds.2010-4097.

Chen, Z. H., G. A. Broderick, N. D. Luchini, B. K. Sloan, and E. Devillard. 2011. Effect of feeding different sources of rumen-protected methionine and milk production and N-utilization in lactating dairy cows. J. Dairy Sci. 94:1978-1988. https://doi.org/10.3168/ jds.2010-3578.

Chilliard, Y., and M. Doreau. 1997. Influence of supplementary fish oil and rumen-protected methionine on milk yield and composition in dairy cows. J. Dairy Res. 64:173-179. https://doi.org/10.1017/ S0022029996002105.

de Ondarza, M. B., S. M. Emanuele, and C. J. Sniffen. 2017. Effect of increased dietary sugar on dairy cow performance as influenced by diet nutrient components and level of milk production. Prof. Anim. Sci. 33:700-707. https://doi.org/10.15232/pas.2017-01648.

Donkin, S. S., G. A. Varga, T. F. Sweeney, and L. D. Muller. 1989 Rumen-protected methionine and lysine: Effects on animal performance, milk protein yield, and physiological measures. J. Dairy Sci. 72:1484-1491. https://doi.org/10.3168/jds.S0022-0302(89)79258 -4 .

El-Gawad, M. A. M. A., and N. S. Ahmed. 2011. Cheese yield as affected by some parameters: Review. Acta Sci. Pol. Technol. Aliment. 10:131-153.

Fahey, A. G., R. M. Marchant-Forde, and H. W. Cheng. 2007. Relationship between body weight and beak characteristics in oneday-old white leghorn chicks: Its implications for beak trimming. Poult. Sci. 86:1312-1315. https://doi.org/10.1093/ps/86.7.1312.

Flis, S. A., and M. Wattiaux. 2005. Effects of parity and supply of rumen-degraded and undegraded protein on production and nitrogen balance in Holsteins. J. Dairy Sci. 88:2096-2106. https://doi .org/10.3168/jds.S0022-0302(05)72886-1.

Gordon, G., C. S. Flitchett, G. S. Plastow, S. A. Papasolomontos, and S. Marsden. 1993. Encapsulated starch for ruminant feed. Dalgety Plc. International publication number WO 93/25616.

Huber, J. T., R. S. Emery, W. G. Bergen, J. S. Liesman, L. Kung Jr., K. J. King, R. W. Gardner, and M. Checketts. 1984. Influences of methionine hydroxy anlog on milk and milk fat production, blood serum lipids, and plasma amino acids. J. Dairy Sci. 67:2525-2531. https://doi.org/10.3168/jds.S0022-0302(84)81609-4.

Jarrige, R. 1989. Ruminant Nutrition: Recommended Allowances and Feed Tables. John Libbey Eurotext, London, UK.

Jenkins, T. C., and M. A. McGuire. 2006. Major advances in nutrition: Impact on milk composition. J. Dairy Sci. 89:1302-1310. https:// doi.org/10.3168/jds.S0022-0302(06)72198-1.

Kidane, A., M. Overland, L. T. Mydland, and E. Prestlokken. 2018. Milk production of Norwegian red dairy cows on silages presumed 
either low or optimal in dietary crude protein content. Livest. Sci. 214:42-50. https://doi.org/10.1016/j.livsci.2018.05.011.

Kröber, T. F., M. Kreuzer, M. Senn, W. Langhans, and F. Sutter. 2000. Lactational and metabolic effects in cows of lysine and methionine added to a ration deficient according to the I.N.R.A method. Arch. Tierernahr. 53:375-394. https://doi.org/10.1080/ 17450390009381959.

Le Henaff, L., H. Rulquin, and R. Verite. 1990. Lactational responses to postruminal infusions of amino acids in dairy cows fed with maize silage, hay or grass silage. Reprod. Nutr. Dev. 30(Suppl. 2):237s. https://doi.org/10.1051/rnd:19900856.

Lean, I. J., P. Celi, H. Raadsma, J. McNamara, and A. R. Rabiee. 2012. Effects of dietary crude protein on fertility: Meta-analysis and meta-regression. Anim. Feed Sci. Technol. 171:31-42. https:// doi.org/10.1016/j.anifeedsci.2011.09.017.

Lee, C., F. Giallongo, A. N. Hristov, H. Lapierre, T. W. Cassidy, K. S. Heyler, G. A. Varga, and C. Parys. 2015. Effect of dietary protein level and rumen-protected amino acid supplementation on amino acid utilization for milk protein in lactating dairy cows. J. Dairy Sci. 98:1885-1902. https://doi.org/10.3168/jds.2014-8496.

McCarthy, R. D., G. A. Porter, and L. C. Griel Jr.. 1968. Bovine ketosis and depressed fat test in milk: A problem of methionine metabolism and serum lipoprotein aberration. J. Dairy Sci. 51:459-462. https://doi.org/10.3168/jds.S0022-0302(68)87007-9.

Moraes, L. E., E. Kebreab, J. L. Firkins, R. R. White, R. Martineau, and H. Lapierre. 2018. Predicting milk protein responses and the requirement of metabolizable protein by lactating dairy cows. J. Dairy Sci. 101:310-327. https://doi.org/10.3168/jds.2016-12507.

NRC. 2001. Nutrient Requirements of Dairy Cattle. 7th rev. ed. Natl. Acad. Sci., Washington, DC.

Nocek, J. E., and S. Tamminga. 1991. Site of digestion of starch in the gastrointestinal tract of dairy cows and its effect on milk yield and composition. J. Dairy Sci. 74:3598-3629. https://doi.org/10.3168/ jds.S0022-0302(91)78552-4.

Noftsger, S., N. R. St-Pierre, and J. T. Sylvester. 2005. Determination of rumen degradability and ruminal effects of three sources of methionine in lactating cows. J. Dairy Sci. 88:223-237. https://doi .org/10.3168/jds.S0022-0302(05)72680-1.

Ordway, R. S., S. E. Boucher, N. L. Whitehouse, C. G. Schwab, and B. K. Sloan. 2009. Effects of providing two forms of supplemental methionine to periparturient Holstein dairy cows on feed intake and lactaitonal performance. J. Dairy Sci. 92:5154-5166. https:// doi.org/10.3168/jds.2009-2259.

Osorio, J. S., P. Ji, J. K. Drackley, D. Luchini, and J. J. Loor. 2013. Supplemental Smartamine M or MetaSmart during the transition period benefits postpartal cow performance and blood neutrophil function. J. Dairy Sci. 96:6248-6263. https://doi.org/10.3168/jds $.2012-5790$.

Overton, T. R., L. S. Emmert, and J. H. Clark. 1998. Effects of source of carbohydrate and protein and rumen-protected methionine on performance of cows. J. Dairy Sci. 81:221-228. https://doi.org/10 .3168/jds.S0022-0302(98)75569-9.

Overton, T. R., D. W. LaCount, T. M. Cicela, and J. H. Clark. 1996. Evaluation of a ruminally protected methionine product for lactating dairy cows. J. Dairy Sci. 79:631-638. https://doi.org/10.3168/ jds.S0022-0302(96)76408-1.

Pacheco, D., R. A. Patton, C. Parys, and H. Lapierre. 2012. Ability of comerically available dairy ration programs to predict duodenal flows of protein and essential amino acids in dairy cows. J. Dairy Sci. 95:937-963. https://doi.org/10.3168/jds.2011-4171.

Pakro, N., and P. Dillon. 1995. Preferential flow, nitrogen transformations and $15 \mathrm{~N}$ balance under urine-affected areas of irrigated and non-irrigated clover-based pastures. J. Contam. Hydrol. 20:329 347. https://doi.org/10.1016/0169-7722(95)00077-1.

Patton, R. A. 2010. Effect of rumen-protected methionine on feed intake, milk production, true milk protein concentration, and true milk protein yield, and the factors that influence these effects: A meta-analysis. J. Dairy Sci. 93:2105-2118. https://doi.org/10 $.3168 /$ jds.2009-2693.
Patton, R. A., A. N. Hristov, and H. Lapierre. 2014. Protein feeding and balancing for amino acids in lactating dairy cows. Vet. Clin. North Am. Food Anim. Pract. 30:599-621. https://doi.org/ 10.1016/j.cvfa.2014.07.005.

Robert, J. C., B. Sloan, B. Saby, J. Mathe, G. Dumont, M. Duron, and E. Dzyzcko. 1989. Influence of dietary nitrogen content and inclusion of rumen-protected methionine and lysine on nitrogen utlization in early lactation dairy cows. Asian-Australas. J. Anim. Sci. 2:544-545. https://doi.org/10.5713/ajas.1989.544.

Samuelson, D. J., S. K. Denise, R. Roffler, R. L. Ax, D. V. Armstrong, and D. F. Romagnolo. 2001. Response of Holstein and Brown Swiss cows fed alfalfa hay-based diets to supplemental methionine at two stages of lactation. J. Dairy Sci. 84:917-928. https://doi .org/10.3168/jds.S0022-0302(01)74549-3.

Schmidt, J., P. Sipócz, E. Cenkvári, and J. Sipócz. 1999. Use of protected methionine (Mepron M85) in cattle. Acta Vet. Hung. 47:409-418. https://doi.org/10.1556/AVet.47.1999.4.2.

Schutz, M. M. 1994. Genetic evaluation of somatic-cell scores for United States dairy cattle. J. Dairy Sci. 77:2113-2129. https://doi.org/ 10.3168/jds.S0022-0302(94)77154-X.

Schwab, C. G. 2012. Amino acids balancing-Is the transition cow interested? Pages 42-57 in Proc. California Nutrion Conference, Fresno, CA.

Schwab, C. G., C. K. Bozak, N. L. Whitehouse, and M. M. A. Mesbah. 1992. Amino acid limitation and flow to duodenum at four stages of lactation. 1. Sequence of lysine and methionine limitation. J. Dairy Sci. 75:3486-3502. https://doi.org/10.3168/jds.S0022 -0302(92)78125-9.

Schwab, C. G., and G. A. Broderick. 2017. A 100-year review: Protein and amino acid nutrition in dairy cows. J. Dairy Sci. 100:1009410112. https://doi.org/10.3168/jds.2017-13320.

Schwab, C.G. and R.S. Ordway. 2004. Balancing diets for amino acids: Implications on production efficiency and feed costs. Pages 1-6 in Penn State Dairy Cattle Nutrition Workshop, Grantville, PA.

Sharma, B. K., and R. A. Erdman. 1988. Abomasal infusion of choline and methionine with or without 2-amino-2methyl-1-propanol for lactating dairy cows. J. Dairy Sci. 71:2406-2411. https://doi.org/ 10.3168/jds.S0022-0302(88)79825-2.

Sinclair, K. D., P. C. Garnsworthy, G. E. Mann, and L. A. Sinclair. 2014. Reducing dietary protein in dairy cow diets: Implications for nitrogen utilization, milk production, welfare and fertility. Animal 8:262-274. https://doi.org/10.1017/S1751731113002139.

Socha, M. T., D. E. Putnam, B. D. Garthwaite, N. L. Whitehouse, N. A. Kierstead, C. G. Schwab, G. A. Ducharme, and J. C. Robert. 2005. Improving intestinal amino acid supply of pre- and postpartum dairy cows with rumen-protected methionine and lysine. J. Dairy Sci. 88:1113-1126. https://doi.org/10.3168/jds.S0022 -0302(05)72778-8

St-Pierre, N. R., and C. S. Thraen. 1999. Animal grouping strategies, sources of variation, and economic factors affecting nutrient balance on dairy farms. J. Anim. Sci. 77(Suppl. 2):72-83. https://doi .org/10.2527/1999.77suppl_272x.

Südekum, K.-H., S. Wolffram, P. Ader, and J.-C. Robert. 2004. Bioavailability of three ruminally protected methionine sources in cattle. Anim. Feed Sci. Technol. 113:17-25. https://doi.org/10.1016/ j.anifeedsci.2003.11.001.

Tyrrell, H. F., and J. T. Reid. 1965. Prediction of the energy value of cow's milk. J. Dairy Sci. 48:1215-1223. https://doi.org/10.3168/ jds.S0022-0302(65)88430-2.

Van Slyke, L. L., and W. V. Price. 1936. Cheese. Orange Judd Publ Cp., Inc., New York, NY.

Van Soest, P. J. 1963. Ruminant fat metabolism with particular reference to factors affecting low milk fat and feed efficiency. A review. J. Dairy Sci. 46:204-216. https://doi.org/10.3168/jds.S0022 $-0302(63) 89008-6$

Van Soest, P. J., J. B. Robertson, and B. A. Lewis. 1991. Methods for dietary fiber, neutral detergent fiber, and nonstarch polysaccharides in relation to animal nutrition. J. Dairy Sci. 74:3583-3597. https://doi.org/10.3168/jds.S0022-0302(91)78551-2. 
Varvikko, T., A. Vanhatalo, T. Jalava, and P. Huhtanen. 1999. Lactation and metabolic responses to graded abomasal doses of methionine and lysine in cows fed grass silage diets. J. Dairy Sci. 82:2659 2673. https://doi.org/10.3168/jds.S0022-0302(99)75523-2.

Whelan, S. J., K. M. Pierce, C. McCarney, B. Flynn, and F. J. Mulligan. 2012. Effect of supplementary concentrate type on nitrogen partitioning in early lactation dairy cows offered perennial ryegrass-based pasture. J. Dairy Sci. 95:4468-4477. https://doi.org/ 10.3168/jds.2011-4689.

Zanton, G. I., G. R. Bowman, M. Vazquez-Anon, and L. M. Rode. 2014. Meta-analysis of lactation performance in dairy cows receiving supplemental dietary methionine sources or postruminal infusion of methionine. J. Dairy Sci. 97:7085-7101. https://doi.org/10 $.3168 /$ jds.2014-8220.
Zhou, Z., M. Vailati-Riboni, E. Trevisi, J. K. Drackley, D. N. Luchini, and J. J. Loor. 2016. Better postpartal performance in dairy cows supplemented with rumen-protected methionine compared with choline during the peripartal period. J. Dairy Sci. 99:8716-8732. https://doi.org/10.3168/jds.2015-10525.

\section{ORCIDS}

F. J. Mulligan (ํ) https://orcid.org/0000-0002-1787-0788

A. G. Fahey (ㅇ https://orcid.org/0000-0002-4594-5767 